\title{
Pengaruh Kualitas Produk Pelayanan dan Persepsi Harga terhadap Kepuasan Pelanggan di PT. Supravisual Mandiri Surabaya
}

\author{
*Vandy Renald, Siti Rosyafah, Indah Noviandari \\ Program Studi Manajemen Fakultas Ekonomi dan Bisnis \\ Universitas Bhayangkara Surabaya, Indonesia
}

DOI: $10.46821 /$ benchmark.v1i2.148

\begin{abstract}
Abstrak
Penelitian ini bertujuan untuk mengetahui dan menguji Pengaruh kualitas produk terhadap kepuasan pelanggan PT. Supravisual Mandiri di Surabaya. Populasi dalam penelitian ini adalah pelangganPT. Supravisual Mandiri di Surabaya. Penelitian ini merupakan penelitian kuantitatif, Sampel yang digunakan dalam penelitian ini ditentukan dengan teknik sensus atau jenuh yaitu sebanyak 100 orang. Teknik analisis pada penelitian ini hanya menggunakan metode analisis regresi linear berganda, koefisien determinasi, uji F (simultan), uji t (parsial), dan uji dominan. Hasil penelitian menunjukkan bahwakualitas produkberpengaruh signifikan terhadap kepuasan pelanggan, pelayanan berpengaruh terhadap kepuasan pelanggan dan persepsi harga berpengaruh signifikan terhadap kepuasan pelanggan. Secaradominan variabel yang mencapai nilai dominan adalah kualitas produk.
\end{abstract}

Kata kunci: Kualitas Produk, Pelayanan, Persepsi Harga dan Kepuasan Pelanggan

\begin{abstract}
The purposes of this research are to know and to examine the influence of product quality, service and price perception to customer satisfaction Supravisual Mandiri company Surabaya. This research is quantitative research using data form a Supravisual Mandiri company Surabaya. This research uses multiple linear regression instrument, coefficient determination, F-test, t-test, and dominant experiment. independent variables in this study consisted of product quality (X1), service (X2) and price perception (X3), whereas for dependent variable is customer satisfaction $(\mathrm{Y})$. The result of this research is product quality significant effect on customer satisfaction, service significant effect on customer satisfaction and price perception significant effect on customer satisfaction.
\end{abstract}

Keywords: Product Quality, Service, Price Perception and Customer Satisfaction.

\section{PENDAHULUAN}

Percetakan merupakan teknologi atau seni yang memproduksi salinan dari sebuah image dengan sangat cepat, seperti kata-kata atau gambar-gambar di atas kertas, kain, dan permukaan-permukaan lainnya. Setiap harinya, milyaran bahan cetak diproduksi, termasuk buku, kalender, buletin, majalah, surat kabar, poster, undangan pernikahan, perangko, kertas dinding, dan bahan kain. Ini karena hasil percetakan dapat dengan cepat mengomunikasikan pemikiran dan informasi ke jutaan orang. Hampir di setiap kota di Indonesia ada perusahaan jasa dibidang percetakan, untuk kebutuhan masyarakat yang digunakan untuk promosi guna menarik para pelanggan, dan hal ini juga membutuhkan pemasar.

*Corresponding Author:

Hal: $105-113$

Email: renaldvandy@gmail.com 
Pemasaran adalah suatu objek yang menjadi kebutuhan seluruh masyarakat baik luar negeri ataupun dalam negeri. Pemasaran sangatlah penting bagi individu ataupun kelompok dimana tujuan pemasaran adalah mengelola sebuah produk jadi untuk menghasilkan sebuah laba, dan laba tersebut dimanfaatkan untuk kelangsungan hidup baik individu atau kelompok yang berkecimpung di dunia bisnis. Berhasil tidaknya suatu kegiatan pemasaran tergantung dari keahlian tenaga pemasar dalam menjalankan prosesnya. Keberhasilan pelaku pemasaran ialah dengan menjual produk dengan harga terjangkau dengan meraup keuntungan yang semaksimal mungkin, dan mampu mengatasi berbagai tantangan dari pesaing terdekatnya. Oleh karena itu para tenaga pemasar harus pandai membaca situasi pasar, diantaranya bisa menarik konsumen dengan berbagai hal, misalnya promosi, produk yang dijual, pelayan, dll.Berdasarkan latar belakang masalah diatas, dalam rangka menganalisis tentang kualitas produk, pelayanan dan persepsi harga yang dapat mempengaruhi pelanggan agar konsumen mencapai kepuasan pada PT. Supravisual Mandiri Surabaya, maka peneliti tertarik untuk melakukan penelitian dengan judul : "Pengaruh Kualitas Produk, Pelayanan dan Persepsi Harga terhadap Kepuasan Pelanggan pada PT. Supravisual Mandiri Surabaya"

\section{TINJAUAN PUSTAKA}

\section{Manajemen Pemasaran}

Manajemen pemasaran terjadi bilamana setidak-tidaknya salah satu pihak dalam pertukaran potensial mempertimbangkan sasaran dan sarana untuk memperoleh tanggapan yag diinginkan pihak lain.

Hasibuan (2016:9), mengemukakan bahwa "manajemen adalah ilmu dan seni mengatur proses pemanfaatan sumber daya manusia dan sumber lainnya secara efektif dan efisien untuk mencapai suatu tujuan tertentu".

\section{Kualitas Produk}

Produk merupakan inti dari sebuah kegiatan pemasaran, karena produk merupakan output atau hasil dari salah satu kegiatan atau aktivitas perusahaan yang dapat ditawarkan kepasar sasaran untuk memenuhi kebutuhan dan keinginan konsumen. Pada dasarnya dalam membeli suatu produk, seorang konsumen tidak hanya membeli produk, akan tetapi konsumen juga membeli manfaat atau keunggulan yang dapat diperoleh dari produk yang dibelinya. Oleh karena itu, suatu produk harus memiliki keunggulan dari produk-produk yang lain, salah satunya dari segi kualitas produk yang ditawarkan. Kualitas produk merupakan salah satu kunci persaingan diantara pelaku usaha yang ditawarkan kepada konsumen. Menurut Kotler dan Keller (2016:156), kualitas adalah totalitas fitur dan karakteristik dari suatu produk atau layanan yang memiliki kemampuan untuk memenuhi kebutuhan yang dinyatakan atau tersirat.

\section{Indikator - Indikator Kualitas Produk}

Menurut David dalam Tjiptono (2016:134), kualitas produk adalah karakteristik dari suatu produk dalam kemampuannya untuk memenuhi kebutuhan-kebutuhan yang telah ditentukan dan mempunyai sifat laten.

Indikator untuk variabel kualitas produk sebagai berikut:

a. Daya tahan produk

b. Keistimewaan produk 
c. Keandalan produk

d. Kesesuaian dengan spesifikasi

e. Estetika produk

\section{PELAYANAN}

Pelayanan adalah proses yang terdiri atas serangkaian aktivitas intangible yang biasa (namun tidak harus selalu) terjadi pada interaksi antara pelanggan dan karyawan, jasa dan sumber daya, fisik atau barang, dan sistem penyedia jasa, yang disediakan sebagai solusi atas masalah pelanggan, yaitu menurut Gronoos dalam Siahahan (2015:22).

Menurut Kotler dalam Siahaan (2015:22), pelayanan merupakan setiap tindakan atau kegiatan yang dapat ditawarkan oleh suatu pihak kepada pihak yang lain, yang pada dasarnya tidak berwujud dan tidak mengakibatkan kepemilikan apapun.

\section{Indikator - Indikator Pelayanan}

Menurut Tjiptono dalam Alfredo Dwitama (2015:398), ia berpendapat bahwa setiap variabelnya memiliki beberapa indikator, yaitu :
a. Kehandalan(Reliability) :
b. Daya Tanggap(Responsiveness) :
c. Nyata (Tangibles) :
d. Empati (Emphaty)
e. Jaminan (Assurance)

\section{Persepsi Harga}

Menurut Achidah dalam Gita (2016:4), persepsi harga merupakan jumlah uang yang telah disepakati oleh calon pembeli dan penjual untuk ditukar dengan barang atau jasa dalam transaksi bisnis normal.

Menurut Wangean dkk. (2014:4), persepsi harga merupakan sejumlah uang yang membebankan atas suatu barang atau produk atau jasa dari jumlah nilai yang ditukarkan konsumen atas keperluan memiliki atau menggunakan produk atau jasa tersebut.

\section{Indikator Persepsi Harga}

Kotler dan Keller (2016:483), persepsi harga adalah salah satu faktor penentu lainnya dalam pemilihan produk yang berkaitan dengan keputusan membeli konsumen. Harga ditentukan berdasarkan negosiasi antara pembeli dan penjual.

Indikator untuk variabel persepsi harga sebagai berikut :
a. Keterjangkauan harga
b. Kesesuaian harga dengan kualitas produk
c. Daya saing harga
d. Potongan harga
e. Kesesuaian harga dengan manfaat produk

\section{Kepuasan Pelanggan}

Kotler dan Amstrong (2015:13), mendefinisikan kepuasan pelanggan adalah tingkatan dimana kinerja produk yang dirasakan memenuhi harapan pembeli.

Kepuasan pelanggan menurut Kotler (2014:150), perasaan senang atau kecewa yang muncul setelah membandingkan kinerja (hasil) produk yang dipikirkan terhadap kinerja (atau hasil) yang diharapkan. 


\section{Indikator Kepuasan Pelanggan}

Menurut Tjiptono (2016:101), ada beberapa indikator dari variabel kepuasan konsumen diantaranya:

a. Kesesuaian harapan

b. Minat membeli kembali

c. Kesediaan merekomendasikan

d. Menciptakan keputusan pembelian pada perusahaan yang sama

e. Menciptakan citra merk

\section{METODE PENELITIAN}

\section{Populasi}

Menurut Sugiyono (2017:80), Populasi adalah wilayah generalisasi yang terdiri atas obyek atau subyek yang mempunyai kualitas dan karakteristik tertentu yang ditetapkan oleh peneliti untuk dipelajari dan kemudian ditarik kesimpulanya. Jadi populasi bukan hanya orang, tetapi juga obyek dan benda benda alam yang lain.

\section{Sampel}

Menurut (Sugiyono, 2017), sampel adalah bagian dari jumlah dan karakteristik yang dimiliki oleh populasi tersebut. Sampel merupakan bagian dari populasi yang diambil untuk mewakili populasi.

Jumlah sampel yang diambil dalam penelitian ini menggunakan rumus Lemeshow, hal ini dikarenakan jumlah populasi tidak diketahui atau tidak terhingga. Berikut rumus Lemesow yaitu :

$\mathrm{n}=\frac{\mathrm{z}_{1-\alpha / 2} \mathrm{P}(1-\mathrm{P})}{\mathrm{d} 2}$

Keterangan :

$\mathrm{n}=$ Jumlah sampel

$\mathrm{z}=$ skor $\mathrm{z}$ pada kepercayaan $95 \%=1.96$

$\mathrm{p}=$ maksimal estimasi $=0,5$

$\mathrm{d}=$ alpha $(0,10)$ atau sampling error $=10 \%$

Melalui rumus diatas, maka jumlah sampel yang akan diambil adalah:

$$
\begin{aligned}
& n=\frac{z_{1-\alpha / 2} \mathrm{P}(1-\mathrm{P})}{\mathrm{d}^{2}} \\
& n=\frac{1,96^{2} \cdot 0,5(1-0,5)}{0,1^{2}} \\
& n=\frac{3,8416 \cdot 0,25}{0,01} \\
& n=96,04=100
\end{aligned}
$$




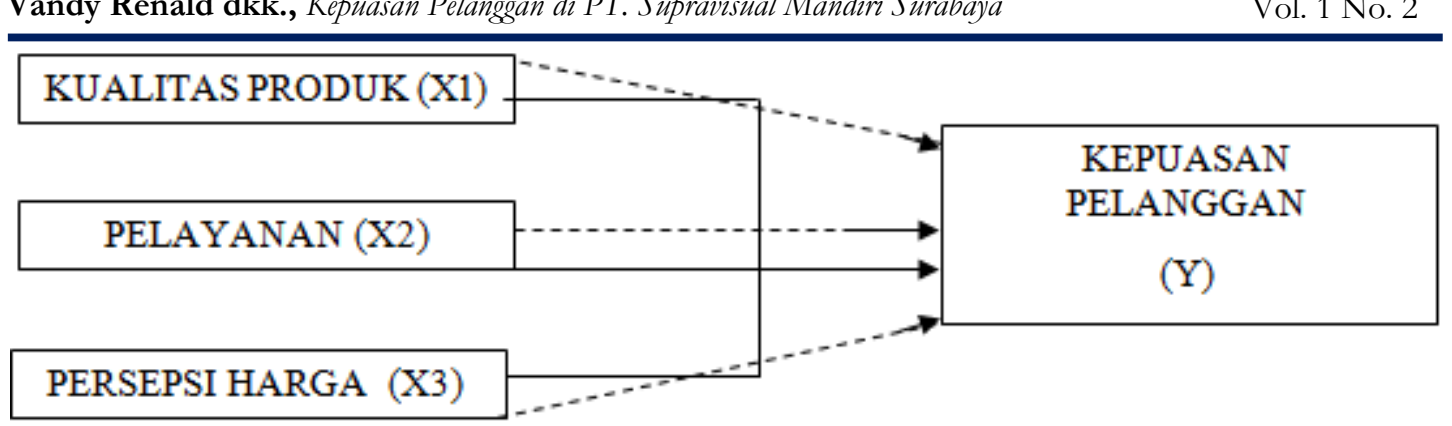

Gambar 1

Kerangka Konseptual

\section{Hipotesis Penelitian}

- Bahwa variabel kualitas produk, pelayanan, dan persepsi harga berpengaruh secara simultan terhadap variabel kepuasan pelanggan di PT. Supravisual Mandiri Surabaya.

- Bahwa variabel kualitas produk, pelayanan, dan persepsi harga berpengaruh secara parsial terhadap variabel kepuasan pelanggan di PT. Supravisual Mandiri Surabaya.

- Bahwa variabel kualitas produk berpengaruh dominan terhadap variabel kepuasan pelanggan di PT. Supravisual Mandiri Surabaya.

\section{Lokasi dan Waktu Penelitian}

- Lokasi dari objek penelitian adalah PT. Supravisual Mandiri di Kecamatan Karang Pilang, Surabaya.

- Waktu penelitian ini dilaksanakan pada bulan Januari 2020 sampai survey lapangan dan pengumpulan data yang dibutuhkan oleh peneliti terpenuhi.

\section{HASIL ANALISIS DAN PEMBAHASAN}

\section{Analisis Linear Berganda}

Regresi linier berganda digunakan untuk memprediksi pengaruh lebih dari satu variabel bebas (independent variable) terhadap satu variabel terikat (dependent variable). Berdasarkan analisis dengan program SPSS diperoleh hasil analisis regresi linier berganda seperti terangkum pada tabel 1.

Tabel 1

Analisis Regresi Linear Berganda Coefficients $^{\mathrm{a}}$

\begin{tabular}{lccccc}
\hline & \multicolumn{2}{c}{$\begin{array}{l}\text { Unstandardized } \\
\text { Coefficients }\end{array}$} & $\begin{array}{c}\text { Standardized } \\
\text { Coefficients }\end{array}$ & & \\
\cline { 2 - 4 } Model & $\mathrm{B}$ & Std. Error & Beta & & T \\
\hline (Constant) & 2.126 & 1.693 & & 1.256 & .212 \\
KUALITAS PRODUK & .425 & .073 & .430 & 5.786 & .000 \\
PELAYANAN & .207 & .068 & .237 & 2.937 & .004 \\
PERSEPSI HARGA & .285 & .066 & .319 & 4.317 & .000 \\
\hline
\end{tabular}

a. Dependent Variable: KEPUASAN

Sumber: Data Diolah, 2020 
Berdasarkan tabel di atas, maka persamaan regresi yang terbentuk pada uji regresi ini adalah :

$\mathrm{Y}=\mathrm{a}+\mathrm{b}_{1} \mathrm{X}_{1}+\mathrm{b}_{2} \mathrm{X}_{2}+\mathrm{b}_{3} \mathrm{X}_{3}$

$\mathrm{Y}=2,126+0,425 \mathrm{X}_{1}+0,207 \mathrm{X}_{2}+0,285 \mathrm{X}_{3}$

Model tersebut dapat diinterprestasikan sebagai berikut :

a. Konstanta (a) sebesar 2,126 memberi arti apabila variabel bebas Kualitas Produk (X1), Pelayanan (X2), Persepsi Harga (X3) bernilai konstan, maka besarnya variabel terikat Kepuasan Pelanggan (Y) sebesar 2,126.

b. Koefesien regresi (b1) untuk Kualitas Produk (X1) memiliki nilai sebesar 0,425. Hal ini menunjukkan hubungan yang searah antara variabel Kualitas produk (X1) terhadap Kepuasan Pelanggan (Y) yaitu jika dalam presentase variabel Kualitas Produk (X1) naik sebesar satu satuan maka Kepuasan Pelanggan (Y) akan mengalami peningkatan sebesar 0,425 satuan.

c. Koefesien regresi (b2) untuk Pelayanan (X2) memiliki nilai sebesar 0,207 Hal ini menunjukkan hubungan yang searah antara variabel Pelayanan (X2) terhadap Kepuasan Pelanggan (Y) yaitu jika dalam presentase Pelayanan (X2) naik sebesar satu satuan maka Kepuasan Pelanggan (Y) akan mengalami penurunan sebesar 0,207 satuan.

d. Koefesien regresi (b3) untuk Persepsi Harga (X3) memiliki nilai sebesar 0,285. Hal ini menunjukkan hubungan yang searah antara variabel Persepsi Harga (X3) terhadap Kepuasan Pelanggan (Y) yaitu jika dalam presentase variabel Persepsi Harga (X3) naik sebesar satu satuan maka Kepuasan Pelanggan (Y) akan mengalami peningkatan sebesar 0,285 satuan.

\section{Uji Simultan ( Uji F )}

Berdasarkan tabel dan pedoman di atas, didapatkan nilai $\mathrm{F}$ sebesar 48,176 berbentuk positif dengan tingkat signifikansi sebesar 0,000 lebih kecil dari 0,05 sehingga Ho diterima serta Ha ditolak. Maka dapat disimpulkan bahwa variabel Persepsi Harga, Kualitas Produk dan Pelayanan secara simultan atau bersama-sama berpengaruh signifikan terhadap Kepuasan Pelanggan PT. Supravisual.

Tabel 2

Hasil Uji Simultan (Uji F)

ANOVA $^{a}$

\begin{tabular}{clccccc}
\hline & Model & Sum of Squares & Df & Mean Square & F & Sig. \\
\hline 1 & Regression & 216.580 & 3 & 72.193 & 48.176 & $.000^{\mathrm{b}}$ \\
& Residual & 143.860 & 96 & 1.499 & & \\
Total & 360.440 & 99 & & & \\
\hline
\end{tabular}

a. Dependent Variable: KEPUASAN

b. Predictors: (Constant), PERESEPSI HARGA, KUALITAS PRODUK, PELAYANAN

Sumber: Data Diolah, 2020 
Tabel 3

\begin{tabular}{|c|c|c|c|c|c|c|}
\hline \multicolumn{7}{|c|}{$\begin{array}{c}\text { Tabel } 3 \\
\text { Hasil Uji Parsial (Uji t) } \\
\text { Coefficients }^{\mathrm{a}}\end{array}$} \\
\hline & \multirow[b]{2}{*}{ Model } & \multicolumn{2}{|c|}{$\begin{array}{c}\text { Unstandardized } \\
\text { Coefficients }\end{array}$} & \multirow{2}{*}{$\begin{array}{c}\begin{array}{c}\text { Standardized } \\
\text { Coefficients }\end{array} \\
\text { Beta }\end{array}$} & \multirow[b]{2}{*}{$\mathrm{T}$} & \multirow[b]{2}{*}{ Sig. } \\
\hline & & $\mathrm{B}$ & Std. Error & & & \\
\hline 1 & (Constant) & 2.126 & 1.693 & & 1.256 & .212 \\
\hline & KUALITAS PRODUK & .425 & .073 & .430 & 5.786 & .000 \\
\hline & PELAYANAN & .201 & .068 & .237 & 2.937 & .004 \\
\hline & PERSEPSI HARGA & .285 & .066 & .319 & 4.317 & .000 \\
\hline
\end{tabular}

Sumber : Data Diolah, 2020

\section{Uji Parsial ( Uji t )}

Dari tabel 3, dapat dilihat ada atau tidaknya pengaruh masing-masing variabel terhadap variabel terikatnya, dapat dianalisis melalui uji t dengan ketentuan berikut:

a. Pengaruh Kualitas Produk terhadap Kepuasan Pelanggan

Variabel Kualitas Produk berpengaruh signifikansi karena menunjukkan angka 0,000yang berarti lebih kecil dari 0,05 (5\%), sehingga dapat disimpulkan bahwa Ho ditolak dan $\mathrm{Ha}$ diterima, artinya bahwa variabelKualitas Produkberpengaruh signifikan terhadap Kepuasan Pelanggan.

b. Pengaruh Pelayanan terhadap Kepuasan Pelanggan

Variabel Pelayanan signifikansi karena menunjukkan angka 0,000 yang berarti lebih kecil dari 0,05 (5\%), sehingga dapat disimpulkan bahwa Ho ditolak dan Ha diterima, artinya bahwa variabel Pelayanan berpengaruh signifikan terhadap Kepuasan Pelanggan.

c. Pengaruh Persepsi Hargaterhadap Kepuasan Pelanggan

Variabel Persepsi Hargaberpengaruh signifikansi karena menunjukkan angka 0,004 yang berarti lebih kecil dari 0,05 (5\%), sehingga dapat disimpulkan bahwa Ho ditolak dan Ha diterima, artinya bahwa Persepsi Harga berpengaruh positifdan signifikan terhadap Kepuasan Pelanggan.

\section{Penentuan Variabel Dominan}

Dari hasil analisis dan pengujian dengan menggunakan program SPSS pada tabel 3, Kualitas Produkmerupakan variabel yang dominan mempengaruhi Kepuasan Pelanggan. Hal ini dapat dilihat dari nilai sig. sebesar 0,000 dimana bernilai lebih kecil dari nilai signifikansi yang sudah ditetapkan yaitu 0,05 dan juga dapat dilihat dari nilai $\beta$ (beta) yang menunjukkan nilai paling besar daripada variabel yang lainnya yaitu 0,430 maka dapat disimpulkan bahwa variabel yang dominan mempengaruhi Kepuasan Pelanggan adalah variabel Kualitas Produk.

\section{SIMPULAN DAN SARAN}

Melalui pengujian secara bersama-sama atau simultan, ketiga variabel ini yaitu Kualitas Produk, Pelayanan dan Persepsi Harga berpengaruh signifikan. Hal ini terbukti dari hasil pengujian secara bersama-sama atau simultan yang menunjukkan angka positif dan lebih kecil dari nilai signifikansi yang sudah ditetapkan atau bisa diartikan bahwa terbukti ketiga variabel independen tersebut mempunyai pengaruh signifikan terhadap variabel 
dependen Kepuasan Pelanggan. Variabel Kualitas Produk secara parsial berpengaruh positif dan signifikan terhadap Kepuasan Pelanggan Pelanggan PT. Supravisual Mandiri. Hal ini dibuktikan dengan koefisien regresi yang menunjukkan angka positif dan tingkat signifikansinya lebih kecil dari nilai signifikansi yang sudah ditetapkan. Variabel Pelayanan secara parsial berpengaruh positif dan signifikan terhadap Kepuasan Pelanggan Pelanggan PT. Supravisual Mandiri. Hal ini dibuktikan dengan koefisien regresi yang menunjukkan angka positif dan tingkat signifikansinya lebih kecil dari nilai signifikansi yang sudah ditetapkan. Variabel Persepsi Harga secara parsial berpengaruh positif dan signifikan terhadap Kepuasan Pelanggan Pelanggan PT. Supravisual Mandiri. Hal ini dibuktikan dengan koefisien regresi yang menunjukkan angka positif dan tingkat signifikansinya lebih kecil dari nilai signifikansi yang sudah ditetapkan. Melalui pengujian secara dominan, dapat diketahui bahwa variabel Kualitas Produk yang berpengaruh dominan terhadap variabel Kepuasan Pelanggan dikarenakan nilai signifikansi yang dihasilkan paling kecil dan nilai $\beta$ (beta) paling tinggi dari pada variabel lainnya. Kualitas Produk sangatlah penting dan harus dijaga oleh PT. Supravisual Mandiri Surabaya. Untuk itu ada hal yang perlu di tingkatkan lebih lagi agar pelanggan merasa puas dengan kualitas produk yang dihasilkan, didalam pernyataan mengenai kualitas produk salah satu indikatornya adalah estetika produk. Perusahaan perlu memperhatikan estetika produknya dari daya tarik yang baik yaitu dengan cara desain yang dibuat haruslah semenarik mungkin, kreatif, inovatif dan komunikatif agar hal tersebut dapat meningkatkan kepuasan pelanggan. Pelayanan merupakan hal yang berpengaruh bagi kepuasan pelanggan PT. Supravisual Mandiri Surabaya. untuk itu indikator yang perlu ditingkatkan lebih lagi yaitu kehandalan (reability). Pegawai perlu dengan cermat melayani permintaan konsumen dalam pembuatan banner hal ini perlu diperhatikan lebih lagi oleh perusahaan terhadap pegawainya, yaitu dengan cara pegawai harus teliti, cermat dan juga mampu mengerjakannya sesuai dengan permintaan pelanggan agar pelanggan merasa puas dengan pelayanan yang diberikan oleh pegawai dari perusahaan tersebut. Persepsi harga merupakan hal yang berpengaruh bagi pelanggan PT. Supravisual Mandiri Surabaya. Dengan indikator potongan harga, hal ini sangatlah perlu ditingkatkan oleh perusahaan yaitu dengan cara memberikan harga diskon secara periode-periode tertentu atau memasang harga yang tidak terlalu tinggi kepada pelanggan agar pelanggan merasa puas dan ingin terus berlangganan di PT. Supravisual Mandiri Surabaya. Bagi peneliti selanjutnya, hendaknya untuk mengembangkan penelitian ini dengan cara menggunakan variabel dan indikator yang berbeda sehingga dapat diperoleh informasi yang lebih lengkap tentang faktor-faktor yang mempengaruhi pengembangan usaha.

\section{DAFTAR PUSTAKA}

Hasan, A. 2013. Marketing. Cetakan Pertama. Media Pressdindo, Yogyakarta.

Hasibuan, Malayu S.P. 2016. Manajemen Sumber Daya Manusia. Edisi Revisi. Jakarta: Penerbit PT Bumi Aksara

Keegan, Warren J. 2014.Global Marketing. ${ }^{\text {th }}$ Edition International Edition. Prentice Hall, USA. 
Kotler Philip, dan Gary Amstrong. 2015. Marketing an Introducing, Global Edition, $12^{\text {th }}$ Edition, Pearson Education.

Kotler Philip, dan Gary Amstrong. 2014. Principles Of Marketing, Global Edition, 14 ${ }^{\text {th }}$ Edition, Pearson Education

Kotler Philip dan Kevin L. Keller. 2016. Marketing Management. Edisi ke 15. Penerbit Pearson Education Limited 2016.

M. Lutfi, Andi (2017). Efek Kualitas Kontruksi Pelayanan Dan Harga Terbadap Volume Penjualan Rumah Di PT. ADI Bintan Permata Batam.

Mullins, John W dan Walker Jr, Orville C. 2013. Marketing Management: A Strategic Decision-Making Approach, ${ }^{\text {th }}$ Edition, McGraw-Hill International Edition.

Soparyanto Dan Rosat. 2015. Manajemen Pemasaran, In Media, Bogor.

Tjiptono, Fandy. 2014. Manajemen Jasa. Yogyakarta : Andi. Yogyakarta. Andi.

Dwitama, Alfredo (2015) Pengaruh Kualitas produk Pelayanan Dan Harga Terbadap Keputusan Pembelian Konsumen D'Stupid Baker Spazio Graba Family Surabaya. 